\title{
A Sebészeti Beavatkozástól Való Félelem Kérdőív magyar nyelvü változatának reliabilitás- és validitásvizsgálata sebészeti beavatkozáson átesett páciensek körében
}

\author{
Wittmann Victoria ${ }^{1}$ - Csabai Márta dr. ${ }^{2}$ - Drótos Gergely ${ }^{2}$ - Lázár György dr. ${ }^{1}$ \\ Szegedi Tudományegyetem, ' Általános Orvostudományi Kar, Sebészeti Klinika, \\ ${ }^{2}$ Bölcsészettudományi Kar, Pszichológiai Intézet, Szeged
}

\begin{abstract}
Bevezetés: Interdiszciplináris kutatásokkal igazolták, hogy a betegek sebészeti beavatkozással kapcsolatos félelmei és szorongásai meghatározó szerepet játszanak a mútét és a mútét utáni felépülés sikerességében.

Célkitüzés: Vizsgálatunk célja az ezen félelmek felmérésére kifejlesztett Sebészeti Beavatkozástól Való Félelem Kérdőív magyar változatának validitás- és reliabilitásvizsgálata volt daganatos megbetegedésben szenvedő személyek körében.

Módszer: Keresztmetszeti vizsgálatunkban 149, sebészeti beavatkozáson átesett páciens vett részt. A skála validitásának vizsgálatára a Spielberger-féle Állapot- és Vonásszorongás Kérdőívet, a Beck Depresszió Kérdőívet és a Vizuális Analóg Skálát használtuk.

Eredmények: A kérdő́iv belső megbízhatósága (Cronbach-alfa = 0,878; 0,885) kiváló. A konstruktumvaliditás vizsgálatakor közepesen szoros összefüggést találtak a szorongás, a depresszió, a mútét utáni vélt fájdalom és a Sebészeti Beavatkozástól Való Félelem Kérdőív között.

Következtetések: A Sebészeti Beavatkozástól Való Félelem Kérdőív magyar verziójának reliabilitása és validitása a vizsgált populáción jónak mutatkozott. A kérdőív megbízható információt ad a mútét előtt álló páciensek mútéttel kapcsolatos rövid távú és hosszú távú félelmeirôl.
\end{abstract}

Orv Hetil. 2018; 159(47): 1988-1993.

Kulcsszavak: szorongás, fájdalom, félelem, sebészeti beavatkozás

\section{The reliability and validity of the Hungarian version of the Surgical Fear Questionnaire}

Introduction: Interdisciplinary studies confirm that surgical fear experienced by patients can have a substantial effect on the outcome of the surgery and the healing process after surgery.

Aim: The aim of this study was to assess the reliability and validity of the Hungarian version of the Surgical Fear Questionnaire in cancer patients.

Method: 149 patients were assessed using the Spielberger Anxiety Inventory, the Beck Depression Inventory, the Visual Analogue Scale and the Surgical Fear Questionnaire.

Results: The scale showed excellent internal consistency (Cronbach-alfa $=0.878 ; 0.885$ ). The Surgical Fear Questionnaire scores moderately correlated with anxiety, depression and anticipated pain after surgery.

Conclusion: The reliability and validity of the Hungarian version of the Surgical Fear Questionnaire in the sample were excellent. The questionnaire turned out to be a useful psychometric tool in the measurement of surgical fear.

Keywords: anxiety, pain, fear, operative surgical procedure

Wittmann V, Csabai M, Drótos G, Lázár Gy. [The reliability and validity of the Hungarian version of the Surgical Fear Questionnaire]. Orv Hetil. 2018; 159(47): 1988-1993.

(Beérkezett: 2018. június 1.; elfogadva: 2018. június 18.) 


\section{Rövidítések}

BDI $=($ Beck Depression Inventory $)$ Beck Depresszió Kérdőív; $\mathrm{FKA}=$ fökomponens-analízis; $\mathrm{KMO}=$ Kaiser-Meyer-Olkinmérőszám; SD = standard deviáció (szórás); SFQ = (Surgical Fear Questionnaire) Sebészeti Beavatkozástól Való Félelem Kérdőív; SFQ-h = hosszú távú félelmek; SFQ-r = rövid távú félelmek; STAI-S = (State-Trait Anxiety Inventory) Spielberger-féle Állapotszorongás Kérdő́ív; STAI-T = (State-Trait Anxiety Inventory) Spielberger-féle Vonásszorongás Kérdőív; VAS $=($ Visual Analogue Scale $)$ Vizuális Analóg Skála

Interdiszciplináris kutatások igazolták, hogy a páciensek sebészeti beavatkozással kapcsolatos félelmei és szorongásai mint rizikófaktorok olyan negatív és megterhelő érzelmi állapotot hozhatnak létre, amely hátráltathatja a páciens fizikai és pszichoszociális felépülését. Mindez összefüggésben állhat az akut és krónikus posztoperatív fájdalom megjelenésével is [1-4].

Számos különbség figyelhető meg abban a tekintetben, hogy a sebészeti beavatkozással kapcsolatos félelmek mire irányulnak. Korábbi kutatások szerint a félelem tárgya az eljövendő mütéttel kapcsolatosan sokféle lehet, mint például: magától a sebészeti eljárástól való félelem, az altatástól való félelem, a vértranszfúziótól való félelem, a tûszúrástól való félelem, a kiszolgáltatottságtól való félelem, a méltóság elvesztésétól való félelem és a haláltól való félelem $[5,6]$. A páciens fájdalommal kapcsolatos elvárásai is kiemelt jelentőségüek lehetnek. Montgomery és mtsai emlődaganatos páciensek körében végzett kutatásukban bebizonyították (2010), hogy a mütét utáni fájdalom mértékével kapcsolatos elvárások sok esetben megjósolták a mütét után ténylegesen megélt fájdalom mértékét [7]. A mütéttől való félelem mértékét a következő tényezők is befolyásolhatják: a mütét típusa, a mütétig hátralévő idő hossza, a mütéttel kapcsolatos előzetes tapasztalatok, az informáltság mértéke a mütéttel kapcsolatosan, kor és nem [4, 8-10].

\section{A Sebészeti Beavatkozástól Való Félelem Kérdőív kidolgozása}

Habár a mütéttel kapcsolatos félelmek mérésére korábban már megjelentek kérdőívek, többségük egy betegségre specifikus, mint például a Bypass Grafting Fear Scale [10] vagy a Surgery Stress Scale [11]. Ezért Theunissen és mtsai (2014) kifejlesztették a Sebészeti Beavatkozástól Való Félelem Kérdő́vet (Surgical Fear Questionnaire, a továbbiakban SFQ) amely tágabb sebészeti betegpopuláción alkalmazható, és amelynek célja, hogy felmérje a páciens mütéttől való félelmének a mértékét [12]. A szerzők 5 különböző prospektív kutatás eredményeinek összevonásával és elemzésével validálták a Sebészeti Beavatkozástól Való Félelem Kérdőívet (3233 fó). A kutatásban részt vevő betegek Hollandiából vagy Portugáliából származtak, és a következő osztályok egyikén estek át sebészeti beavatkozáson: általános sebészet, plasztikai se- bészet, ortopédia, nőgyógyászat, fül-orr-gégészet, urológia, idegsebészet. A mérőeszköz megbízhatóságát a Cronbach-alfa mutató segítségével ellenőrizték.

\section{A vizsgálat célja}

A jelen kutatásban az SFQ magyar változatát és a kérdőív pszichometriai jellemzőit mutatjuk be daganatos megbetegedésben szenvedő személyek mintáján. Felmérjük az SFQ faktorszerkezetét, validitását és megbízhatósági mutatóit. A megbízhatóság és a konkurens validitás ellenőrzése céljából felmértük a páciensek érzelmi és hangulati állapotát, illetve a várt és a ténylegesen észlelt fájdalom mértékét.

\section{Módszer}

\section{Résztvevők és a vizsgálat körülményei}

A vizsgálati mintába a Szegedi Tudományegyetem Sebészeti Osztályának mütét előtt álló, 18 évnél idősebb, daganatos megbetegedéssel diagnosztizált fekvő betegei kerültek beválasztásra. A vizsgálat 2017. január és április között zajlott. A tesztcsomag kitöltése mútét előtt 1 nappal és mútét után 2 nappal, önkéntes alapon történt a klinika fekvőbeteg-osztályán. A kutatást a Regionális Humán Orvosbiológiai Kutatásetikai Bizottság engedélyezte (protokollszám: SURG-PSZI-001). Összesen 149, sebészeti mútétre váró daganatos páciens került a mintába (47 férfi, átlagéletkoruk 62,74 év; SD = 12,30; illetve 102 nő, átlagéletkoruk 55,61 év; SD = 13,51). A páciensek közül 63 fó emlőmútéten ( 37 fó excisio, 26 fó mastectomia), 38 fö hasi mútéten (26 fö laparoscopia, 12 fó laparotomia), 36 fó tüdőmútéten ( 24 fö thoracoscopia, 12 fö thoracotomia) és 12 fő egyéb mútéten esett át.

\section{Pszichológiai méröeszközök}

Beck Depresszió Kérdöív (BDI) - A 21 tételes kérdöív 4 fokú Likert-skálán a depresszió egyes tüneteire kérdez rá, úgymint fáradékonyság, alvászavar, döntésképtelenség, túlzott aggódás, az elégedettség hiánya, önmagunk vádolása $[13,14]$.

Spielberger-féle Vonás-és Állapotszorongás Skála (STAI$T$ és STAI-S) - Ezt a 40 tételes kérdőívet a szorongás szintjének mérésére alkalmaztuk, amelynél a vonásszorongás kérdőív a szorongás általános szintjét méri, míg az állapotszorongás az éppen aktuális szorongást jelzi. A kérdőív 4 fokú Likert-skálán mér $[15,16]$.

Sebészeti Beavatkozástól Való Félelem Kérdoín (SFQ) A kérdőív kifejezetten sebészeti beavatkozáson átesett betegek mütéttől való félelmét méri [12]. A kérdőív 10 itemből áll, és 10 fokú Likert-skálán értékelhető. A kérdőív 2 alskálát tartalmaz. A „Rövid távú félelmek” skála (a továbbiakban: SFQ-r) a mútét kimenetelével kapcso- 
latos rövid távú félelmekre kérdez rá, mint a fájdalomtól és az altatástól való félelem. A „Hosszú távú félelmek” skála (a továbbiakban: SFQ-h) a mütét kimenetelével kapcsolatos hosszú távú félelmekre kérdez rá, mint a hosszú rehabilitációtól való félelem. A szemantikai és tartalmi azonosság elérése érdekében a kérdőívet három független fordító magyarra fordította, majd a fordítók megállapodtak egy közös változatban, amelyet egy negyedik fordító visszafordított angolra. A visszafordított és az eredeti kérdőíveket a fordítók összevetették, és a javaslatok alapján megalkották a végleges verziót.

Vizuális Analóg Skála (VAS) - A fájdalom mérésére szolgáló kérdőív, 10 fokú Likert-skálával [17]. A mütét előtt a mütét utáni vélt fájdalom mértékére kérdeztünk rá, míg a mútét után 2 nappal a ténylegesen megélt fájdalom mértékét mértük fel.

\section{Statisztikai eljárások}

Az adatbevitelt és a statisztikai elemzést az SPSS 23-as és az AMOS 21-es verziójával végeztük (IBM Corp., Armonk, NY, Amerikai Egyesült Államok). A statisztikai szignifikancia határát a korrelációs vizsgálatok kivételével p<0,05-ös szinten határoztuk meg, az együttjárások esetében az első fajú hiba alacsonyan tartásának érdekében Bonferroni-korrekciót alkalmaztunk (a szigorított szint: p<0,005). A kérdóív validálásának érdekében fókomponens-analízis (FKA) segítségével vizsgáltuk, hogy a teszt kidolgozása során kialakított skálák a magyar minta esetében is azonosíthatók-e. A szakirodalomban meghatározott irányelvek szerint azokat az itemeket tartottuk meg az FKA során, amelyek közös faktorsúlyának hatása 0,25-nél magasabb volt, illetve az egynél magasabb sajátértékű főkomponenseket tekintettük megfelelőnek. A FKA megbízhatóságának alátámasztásához az itemek egymás közötti korrelációit és a Kaiser-Meyer-Olkinmérőszám (KMO) értékét, valamint a Bartlett-teszt

1. táblázat A Sebészeti Beavatkozástól Való Félelem Kérdőív (SFQ) főkomponenssúlyai

\begin{tabular}{|c|c|c|}
\hline \multirow[t]{2}{*}{ Állítások } & \multicolumn{2}{|c|}{ Fókomponens } \\
\hline & SFQ-r & SFQ-h \\
\hline $\begin{array}{l}\text { 4. Félek a mütét utáni kellemetlen mellékhatá- } \\
\text { soktól (mint például a hányinger). }\end{array}$ & 0,903 & \\
\hline 3. Félek a mútét utáni fájdalomtól. & 0,887 & \\
\hline 2. Félek az érzéstelenítéstől. & 0,808 & \\
\hline 1. Félek a mútéttől. & 0,781 & \\
\hline $\begin{array}{l}\text { 9. Félek, hogy nem fogok teljesen felépülni a } \\
\text { műtét után. }\end{array}$ & & 0,939 \\
\hline 6. Félek, hogy a mütét nem sikerül. & & 0,924 \\
\hline $\begin{array}{l}\text { 10. Félek a mútétet követő hosszú rehabilitáció- } \\
\text { tól. }\end{array}$ & & 0,680 \\
\hline $\begin{array}{l}\text { 5. Félek, hogy a mútét miatt romlani fog az } \\
\text { egészségem. }\end{array}$ & & 0,506 \\
\hline
\end{tabular}

SFQ-h = hosszú távú félelmek; SFQ-r = rövid távú félelmek eredményét vizsgáltuk. Az itemek fookomponensekhez tartozásának könnyebb értelmezése érdekében pedig ferde forgatást (direct oblimin) választottunk, és a 0,4nél magasabb súlyokat tekintettük megfelelően magasnak. Az adatok elemzéséhez megvizsgáltuk a STAI, BDI kérdőívek és az SFQ skáláinak normális eloszlását Shapiro-Wilk-féle normalitásvizsgálattal, valamint a ferdeségi és csúcsossági mutatókat is áttekintettük. Az eloszlásvizsgálatok alapján a vizsgálati személyek kérdőívei közötti kapcsolat elemzéséhez nemparaméteres eljárásokat használtunk. A skálák belső megbízhatóságát Cronbach-alfa mérőszámmal jellemeztük. A konkurens validitás megállapítása érdekében Spearman-féle rangkorrelációt számítottunk. A mütéti csoportok összehasonlítására MannWhitney-tesztet alkalmaztunk.

\section{Eredmények}

\section{Faktorelemzés}

Az SFQ-FKA során kezdeti lépésben mind a tíz kérdés alapján próbáltuk meghatározni a skálákat, azonban a hetedik és a nyolcadik kérdés esetében a faktorsúlyok alapján nem volt egyértelmúen eldönthető, hogy a rövid távú vagy a hosszú távú következményekkel kapcsolatos félelmekhez tartoznak-e, ezért a teszt kidolgozói által is javasolt 8 itemes kérdőív bizonyult jól használhatónak. Az elemzés alapján nincsenek redundáns kérdések a kérdőívben, az egyes itemek közötti korreláció nem haladta meg az $\mathrm{r}=0$,9-es értéket, a $\mathrm{KMO}=0,86$ alapján megfelelő az itemek közös információtartalma és a mintanagyság, továbbá a Bartlett-teszt szignifikáns eredménye alapján (khi-négyzet $(28)=798,274$, p <0,001) is alkalmas az adatbázis FKA-ra. A kérdések közös faktorsúlyainak hatásai megfelelőek (>0,65), a feltárt főkomponensek pedig egynél magasabb sajátértékkel rendelkeztek. A rövid távú következményekkel kapcsolatos félelmek sajátértéke 4,98, míg a hosszú távú következményekkel kapcsolatos félelmeké 1,043, a megmagyarázott variancia pedig $75,3 \%$. A főkomponenssúlyok alapján jól azonosíthatók a rövid távú és a hosszú távú következményektől való félelmek (1. táblázat), az egyes kérdések súlyai az elvárt 0,4 -es szint fölött voltak.

\section{A megbizhatóság vizsgálata}

A két skála megbízhatóságát a belső konzisztencia megállapítására legelfogadottabb mérőszámmal, a Cronbachféle alfa-együttható meghatározásával ellenóriztük [18]. A két skála belső megbízhatóságának vizsgálata alapján az SFQ-r Cronbach-alfa-értéke 0,878, míg az SFQ-h esetében 0,885 volt; mindkét érték megfelelóen magasnak számít, belső megbízhatóságot jelez (2. táblázat). A kérdőív gyakorlati felhasználásához igazodva nem a fókomponensek értékeit, hanem a megfigyelt struktúra alapján számított összegeket használtuk a további elemzésekben. 
2. táblázat A Sebészeti Beavatkozástól Való Félelem Kérdőív (SFQ) fókomponenseinek belső megbízhatósági mutatói és leíró statisztikája

\begin{tabular}{llllll}
\hline & $\begin{array}{l}\text { Cronbach-alfa } \\
\text { (tételszám) }\end{array}$ & Minimum & Maximum & M & SD \\
\hline SFQ-r & $\begin{array}{l}0,878 \\
(4)\end{array}$ & 0 & 40 & 18,8 & 10,69 \\
\hline SFQ-h & $\begin{array}{l}0,885 \\
(4)\end{array}$ & 0 & 40 & 14,9 & 10,95 \\
\hline
\end{tabular}

$\mathrm{M}=$ átlag; $\mathrm{SD}=$ standard deviáció (szórás); SFQ-h = hosszú távú félelmek; SFQ-r = rövid távú félelmek

\section{Validitásvizsgálat}

A validitásvizsgálatba bevont skálák között szerepel az Állapot- és Vonásszorongás Kérdőív, a Beck Depresszió Kérdőív és a Vizuális Analóg Skála.

A konvergens validitás esetében a STAI állapotszorongás skálájával az SFQ-r $\left(\mathrm{r}_{\mathrm{s}}(147)=0,49, \mathrm{p}<0,001\right)$ és az SFQ-h $\left(\mathrm{r}_{\mathrm{s}}(147)=0,42, \mathrm{p}<0,001\right)$ közepes erősségú együttjárást mutatott, a vonásszorongással pedig gyenge korreláció mutatkozott mindkét érték esetében (SFQ-r: $\mathrm{r}_{\mathrm{s}}(147)=0,32, \mathrm{p}<0,001 ;$ SFQ-h: $\mathrm{r}_{\mathrm{s}}(147)=0,39$, $\mathrm{p}<0,001)$. A szorongáshoz hasonlóan a depressziós tünetek súlyosságával (BDI) az SFQ-r gyengén $\left(\mathrm{r}_{\mathrm{s}}(146)=\right.$ $0,35, \mathrm{p}<0,001)$, az SFQ-h közepesen erösen $\left(\mathrm{r}_{\mathrm{s}}(146)=\right.$ $0,44, \mathrm{p}<0,001)$ járt együtt.

Az SFQ skálái közepesen erős korrelációt mutattak a fájdalom vizuális skálájának operáció előtti értékével (SFQ-r: $\mathrm{r}_{\mathrm{s}}(134)=0,52, \mathrm{p}<0,001 ;$ SFQ-h: $\mathrm{r}_{\mathrm{s}}(134)=0,48$, $\mathrm{p}<0,001)$, azonban nem jártak együtt az operáció után tapasztalt fájdalommal.

\section{Összefüggés a szociodemográfiai változókkal}

A kérdőív skáláin mért értékek nem különböztek jelentősen a férfiak és a nők között ( $p$ minden esetben >0,05). Az SFQ-h skála gyenge korrelációt mutatott az iskolai végzettséggel $\left(\mathrm{r}_{\mathrm{s}}=-0,181, \mathrm{p}=0,029\right)$. Az SFQ-r és a szociodemográfiai változók között nem találtunk szignifikáns összefüggést ( $\mathrm{p}$ minden esetben $>0,05$ ). A családi állapot és az életkor egyik skálával sem mutatott szignifikáns korrelációt ( $\mathrm{p}$ minden esetben $>0,05$ ).

\section{Összefüggés a mütét típusa és a fájdalom között}

Eredményeink alapján az emlőmütéten átesett pácienseknél a mútét típusa (excisio vagy mastectomia) nem befolyásolta szignifikánsan a mütét előtti vélt fájdalom, valamint a mútét utáni fájdalom mértékét ( $\mathrm{p}$ minden esetben $>0,05)$. A hasi mütéten átesett pácienseknél a mútét típusa (laparoscopia vagy laparotomia) szintén nem befolyásolta szignifikánsan a mütét előtti vélt fájdalom, valamint a mütét utáni fájdalom mértékét ( $\mathrm{p}$ minden esetben >0,05). Az előző eredményekhez hasonlóan nem találtunk szignifikáns különbséget a tüdőműtéten átesett pácienseknél a mútét típusa (thoracoscopia vagy thoracotomia) és a fájdalom között ( $\mathrm{p}$ minden esetben $>0,05)$.

\section{Megbeszélés}

Tanulmányunkban a sebészeti beavatkozással kapcsolatos félelmek mérésére alkalmazható Sebészeti Beavatkozástól Való Félelem Kérdőív magyar változatát ismertettük (Melléklet). A kutatás során felmértük a daganatos páciensek érzelmi és hangulati állapotát és a mútét előtti vélt fájdalom és a mútét utáni megélt fájdalom mértékét.

Az eredményekből megállapítható, hogy a kérdőív pszichometriai mutatói megfelelőek, az általunk mért belső konzisztenciája és a skálák megbízhatósága egyaránt jónak mondható. Az elemzések alapján az SFQ magyar változatának struktúrája nagyon hasonló képet mutat, mint az eredeti angol nyelvű kérdőív; eredményeink szerint két skála, a mútét rövid távú és hosszú távú következményeitől való félelem mérésére szolgáló két dimenzió hozható létre nyolc kérdés alapján [12]. Kutatásunkban az SFQ-értékeket a nem, a kor, az iskolai végzettség és a családi állapot nem befolyásolta szignifikánsan. A validitás vizsgálatakor több gyenge és közepes mértékű korrelációt találtunk a kérdőív és az érzelmi-hangulati állapot, illetve a mútét utáni vélt fájdalom között. A konvergens validitás mérésekor tehát bizonyítást nyert, hogy a kérdőívek hasonló fogalmi konstruktumokat mérnek, de nem teljesen ugyanazt.

Az SFQ kérdőív „Rövid távú félelmek” skálája közepes összefüggést mutatott az állapotszorongás és a mütét előtti vélt fájdalom mértékével. A kérdőív „Hosszú távú félelmek" skálája szintén közepes összefüggést mutatott az állapotszorongás és a mütét előtti vélt fájdalom mértékével, továbbá a depresszió mértékével is. Nem találtunk azonban kapcsolatot a sebészeti beavatkozással kapcsolatos félelmek és a mütét utáni fájdalom között. Eredményeink szerint tehát a páciens mütét előtt megélt félelmei a mütét rövid távú és hosszú távú következményeivel kapcsolatban kihatással vannak a beteg érzelmi jóllétére, azonban nem jelzik előre a mütét utáni fájdalmat, inkább a személy szubjektív viszonyát jellemzik a mútéti beavatkozással kapcsolatban. Jelen mintákban a mútét típusa nem befolyásolta a mütét utáni fájdalom mértékét.

\section{Következtetések}

A kutatócsoportunk által magyar nyelvre adaptált Sebészeti Beavatkozástól Való Félelem Kérdőív segítségével alátámasztást nyert, hogy a mútéttel kapcsolatos félelmek, fantáziák befolyásolják a páciens érzelmi állapotát. A kutatás korlátai a hozzáférhetôségi mintavétel, a viszonylag alacsony mintaelemszám, a mütéti csoportok közötti egyenlőtlen eloszlás és a keresztmetszeti kutatási elrendezés. 
A kérdőív segítségével szeretnénk felmérni, hogy milyen félelmei vannak az Ön előtt álló sebészeti beavatkozással kapcsolatban. Kérem, karikázza be azt a számot, amely véleménye szerint a leginkább tükrözi jelenlegi érzéseit.

1. Félek a mútéttől.

0 l

Egyáltalán nem félek.

23

3

4

5

6

7

8

$9 \quad 10$

2. Félek az érzéstelenítéstól.

$\begin{array}{llllllllrr}0 & 1 & 2 & 3 & 4 & 5 & 6 & 7 & 8 & 9 \\ \text { Egyáltalán nem félek. } & & & & & & & & & \text { Nagyon félek. }\end{array}$

\section{Félek a mütét utáni fájdalomtól.}

$\begin{array}{llllllllrrr}0 & 1 & 2 & 3 & 4 & 5 & 6 & 7 & 8 & 9 \\ \text { Egyáltalán nem félek. } & & & & & & & & & \text { Nagyon félek. }\end{array}$

\section{Félek a mútét utáni kellemetlen mellékhatásoktól (mint például a hányinger).}

$\begin{array}{lllllll}0 & 1 & 2 & 3 & 4 & 5 & 6\end{array}$

Egyáltalán nem félek.

5. Félek, hogy a mútét miatt romlani fog az egészségem.

$\begin{array}{llllllll}0 & 1 & 2 & 3 & 4 & 5 & 6\end{array}$

Egyáltalán nem félek.

6. Félek, hogy a mütét nem sikerül.

$\begin{array}{lllllll}0 & 1 & 2 & 3 & 4 & 5 & 6\end{array}$

Egyáltalán nem félek.

4

\section{Félek a kórházi tartózkodástól.}

$\begin{array}{lllll}0 & 1 & 2 & 3 & 4\end{array}$

Egyáltalán nem félek.

8. Aggódom a családom miatt.

$\begin{array}{llllllll}0 & 1 & 2 & 3 & 4 & 5 & 6\end{array}$

Egyáltalán nem félek.

9. Félek, hogy nem fogok teljesen felépülni a mütét után.

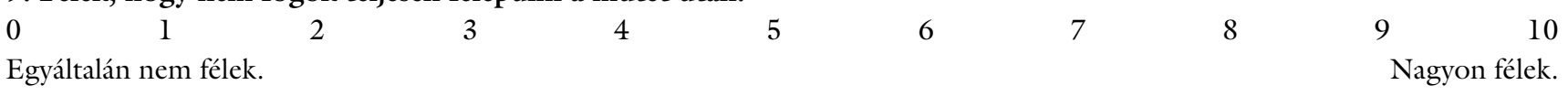

10. Félek a mütétet követő hosszú rehabilitációtól.

$\begin{array}{llllllllll}0 & 1 & 2 & 3 & 4 & 5 & 6 & 7 & 8 & 9 \\ \text { Egyáltalán nem félek. } & & & & & & & & & \end{array}$

Skálaképzési útmutató:

A skálaképzés az adott skálához tartozó tételek összeadásával történik.

Rövid távú félelmek skála: 1., 2., 3. és 4 . tétel

Hosszú távú félelmek skála: 5., 6., 9. és 10. tétel

A mindennapos sebészeti gyakorlatban ritkán van lehetőség arra, hogy részletesen felmérésre kerüljön a páciens mütét előtti aktuális pszichés állapota. Kérdőívünk segítségével könnyebben és gyorsabban felmérhetővé válhat, hogy mik azok a legfóbb félelmek a sebészeti beavatkozással kapcsolatban, amelyek szorongással töltik el a pácienst, és amelyek átbeszélése segítheti a pácienst re- ális vagy irreális félelmeinek csökkentésében. A páciens mútéttel kapcsolatos rövid és hosszú távú félelmeinek mérséklése pozitív irányba hangolhatja a beteg együttmúködését, beleegyezését, és javíthatja az orvos-beteg kommunikációt is, amely daganatos betegségek esetén különösen nehezített lehet [19]. Ezenkívül érdemes lehet a páciensek egészségmúveltségét is felmérni, hiszen 
az orvosi információk megértésének mértéke is jelentősen meghatározhatja a gyógyítás sikerességét [20]. Kutatásunk a mútét előtti pszichológiai intervenció és szorongáscsökkentés fontosságára hívja fel a figyelmet, amelyek a mútét előtt álló páciens minél teljesebb pszichés felkészülését szolgálják a mútéti beavatkozásra [2123].

Anyagi támogatás: A közlemény megírása, illetve a kapcsolódó kutatómunka anyagi támogatásban nem részesült.

Szerzői munkamegosztás: W. V.: A kutatás megtervezéséért, az adatgyújtésért, az adatok statisztikai értelmezéséért és a publikáció megírásáért volt felelős. Cs. M.: A kutatási terv kidolgozásában, az eredmények értelmezésében és a kézirat megírásában nyújtott segítséget. D. G.: Az adatok statisztikai értelmezésében és a publikáció megírásában nyújtott segítséget. L. Gy.: A kutatási kérdés megfogalmazásában és az adatgyưjités lefolytatásában vett részt. A cikk végleges változatát valamennyi szerző elolvasta és jóváhagyta.

Érdekeltségek: A szerzőknek nincsenek érdekeltségeik.

\section{Irodalom}

[1] Ali A, Altun D, Oguz BH, et al. The effect of preoperative anxiety on postoperative analgesia and anesthesia recovery in patients undergoing laparascopic cholecystectomy. J Anesth. 2014; 28: 222-227.

[2] Munafò MR, Stevenson J. Anxiety and surgical recovery: Reinterpreting the literature. J Psychosom Res. 2001; 51: 589-596.

[3] Theunissen M, Peters ML, Bruce J, et al. Preoperative anxiety and catastrophizing: a systematic review and meta-analysis of the association with chronic postsurgical pain. Clin J Pain 2012; 28: 819-841.

[4] Zieger M, Schwarz R, König HH, et al. Depression and anxiety in patients undergoing herniated disc surgery: relevant but underresearched - a systematic review. Cent Eur Neurosurg. 2010 71: 26-34.

[5] Koivula M, Tarkka MT, Tarkka M, et al. Fear and anxiety in patients at different time-points in the coronary artery bypass process. Int J Nurs Stud. 2002; 39: 811-822.

[6] Shafer A, Fish MP, Gregg KM, et al. Preoperative anxiety and fear: a comparison of assessments by patients and anesthesia and surgery residents. Anesth Analg. 1996; 83: 1285-1291.

[7] Montgomery M, McCrone SH. Psychological distress associated with the diagnostic phase for suspected breast cancer: systematic review. J Adv Nurs. 2010; 66: 2372-2390.

[8] Carr E, Brockbank K, Allen S, et al. Patterns and frequency of anxiety in women undergoing gynaecological surgery. J Clin Nurs. 2006; 15: 341-352.
[9] Caumo W, Schmidt AP, Schneider CN, et al. Risk factors for preoperative anxiety in adults. Acta Anaesthesiol Scand. 2001; 45: 298-307.

[10] Koivula M, Tarkka MT, Tarkka M, et al. Fear and in-hospital social support for coronary artery bypass grafting patients in the day before surgery. Int J Nurs Stud. 2002; 39: 415-427.

[11] Rosenberger PH, Kerns R, Jokl P, et al. Mood and attitude predict pain outcomes following arthroscopic knee surgery. Ann Behav Med. 2009; 37: 70-76.

[12] Theunissen M, Peters ML, Schouten EG, et al. Validation of the Surgical Fear Questionnaire in adult patients waiting for elective surgery. PloS ONE 2014; 9: e100225.

[13] Beck AT, Ward CH, Mendelson M, et al. An inventory for measuring depression. Arch Gen Psychiatry 1961; 4: 561-571.

[14] Rózsa S, Szádóczky E, Füredi J. Characteristics of the Beck Depression Scale in Hungarian sample. [A Beck Depresszió Kérdőív rövidített változatának jellemzői hazai mintán.] Psychiatr Hung. 2001; 16: 384-402. [Hungarian]

[15] Sipos K, Sipos M, Spielberger CD. Hungarian version of the State-Trait Anxiety Inventory (STAI). In: Mérei F, Szakács F. (eds.) Psycholodiagnostic Vademecum, I. Explorational and biolgraphic methods, symptom evaluation scales and questionnaires, 2. [A State-Trait Anxiety Inventory (STAI) magyar változata. In: Mérei F, Szakács F. (szerk.) Pszichodiagnosztikai Vademecum I. Explorációs és biográfiai módszerek, tünetbecslő skálák, kérdő́ivek 2.] Tankönyvkiadó, Budapest, 1988; pp. 123136. [Hungarian]

[16] Spielberger CD, Gorsuch RL, Lushene RE. Manual for the State-Trait Anxiety Inventory. Consulting Psychologists Press, Palo Alto, CA, 1970

[17] Wong DL, Baker CM. Smiling face as anchor for pain intensity scales. Pain 2001; 89: 295-297.

[18] Cronbach LJ. Essentials of psychological testing (5th edn.). Harper \& Row, New York, NY, 1990.

[19] Muszbek K, Gaal I. Pitfalls within the cancer-related doctorpatient communication. [Az orvos-beteg kommunikáció csapdái daganatos betegség esetén.] Orv Hetil. 2016; 157: 649-653. [Hungarian]

[20] Papp-Zipernovszky O, Náfrádi L, Schulz PJ, et al. "So each patient comprehends": measuring health literacy in Hungary. [„Hogy minden beteg megértse!” - Az egészségmúveltség (health literacy) mérése Magyarországon.] Orv Hetil. 2016; 157: 905-915. [Hungarian]

[21] Tsimopoulou I, Pasquali S, Howard R, et al. Psychological prehabilitation before cancer surgery: a systematic review. Ann Surg Oncol. 2015; 22: 4117-4123.

[22] Nelson EA, Dowsey MM, Knowles SR, et al. Systematic review of the efficacy of pre-surgical mind-body based therapies on postoperative outcome measures. Complement Ther Med. 2013;21: 697-711.

[23] Silver JK, Baima, J. Cancer prehabilitation: an opportunity to decrease treatment-related morbidity, increase cancer treatment options, and improve physical and psychological health outcomes. Am J Phys Med Rehabil. 2013; 92: 715-727.

Wittmann Victoria,

Szeged, Semmelweis u. 8., 6720 e-mail: victoriawittmann1@gmail.com) 